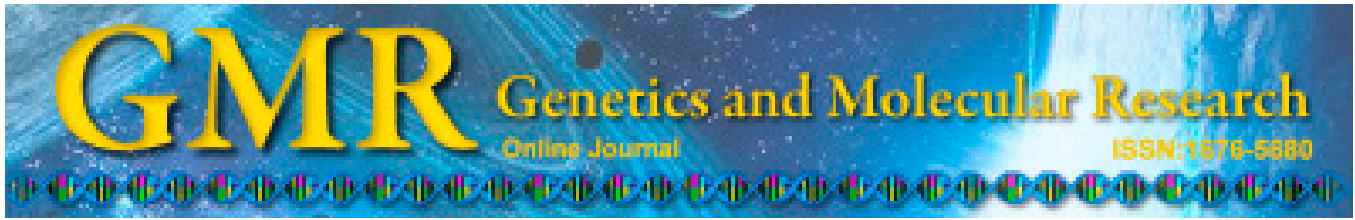

\title{
Genetic relationships analysis of olive cultivars grown in China
} \author{
Z.S. Yang' ${ }^{2}$ Z. Shan ${ }^{3}$ and Q.M. Huang ${ }^{1}$ \\ *These authors contributed equally to this study. \\ Corresponding author: Q.M. Huang \\ E-mail: hqming@sicau.edu.cn \\ Genet. Mol. Res. 14 (2): 5958-5969 (2015) \\ Received August 15, 2014 \\ Accepted January 19, 2015 \\ Published June 1, 2015 \\ DOI http://dx.doi.org/10.4238/2015.June.1.13
}

M.M. Zhan ${ }^{1 *}$, Z.Z. Cheng ${ }^{1 *}$, G.C. $\mathrm{Su}^{2}$, A.Y. Wang ${ }^{2}$, H.P. Chen ${ }^{1}$,

${ }^{1}$ College of Science, Sichuan Agricultural University, Yaan, China ${ }^{2}$ Liang Shan Zhong Ze New Technology Development Co., Ltd., Xichang, China ${ }^{3}$ College of Life Sciences, Sichuan Agricultural University, Yaan, China

ABSTRACT. The olive tree is an iconic tree of the Mediterranean, and is used extensively to produce high-quality olive oil. Although the China olive industry has just begun to be valued, there were also existed mislabeling and synonyms in introduced cultivars. The aim of this study was to analyze genetic similarities among olive cultivars in China using SSR and ISSR techniques. Thirty-two samples were collected from Xichang. Five of these cultivars were issued from a Chinese breeding program. Genomic DNA samples were extracted from young leaves and PCR was used to generate SSR and ISSR markers. A total of 107 polymorphic bands were detected on thirteen SSR loci, with an average of eight alleles per locus. The observed heterozygosity ranged from 0.785 (DCA03) to 0.990 (GAPU47), and the expected heterozygosity varied between 0.782 (DCA03) and 0.940 (GAPU103A). The discrimination power ranged from 0.57 to 0.83 , while the polymorphism information content values ranged from 0.768 (DCA03) to 0.934 (GAPU103A). Nine ISSR primers generated 85 reproducible bands of which $78(91.8 \%)$ were polymorphic. Based 
on our data, genetic similarity between cultivars ranged from 0.57 to 0.83 . Cluster analysis revealed that 32 cultivars were clustered into six groups, which supports similar morphology such as use, oil content and fruit weight but not similar geographical origins. Our data also allow the identification of unknown cultivars and cases of synonyms.

Key words: Olea europaea L.; Cultivar identification; SSR, ISSR, Genetic similarity; Genetic diversity

\section{INTRODUCTION}

The olive tree $(2 \mathrm{n}=2 \mathrm{x}=46)$ is an ancient woody crop with more than 46,000 years of cultural history, and is mainly distributed around the Mediterranean basin. In recent decades, olive trees have been introduced and cultivated in the United States, Australia, South Africa, China and in other countries (Breton et al., 2006). Olive has become one of the major oil crops in some countries because it can produce a high quality oil with great economic value (Bandelj et al., 2004).

At present, olive cultivars are identified using biochemical and molecular markers such as isoenzymes (Lumaret et al., 2004), RAPDs (Martins-Lopes et al., 2008), AFLPs (Montemurro et al., 2008), SSRs (Sefc et al., 2000; Cipriani et al., 2002; Erre et al., 2010), ISSRs (Souza et al., 2012), SCARs (Pafundo et al., 2007), and SNPs (Belaj et al., 2012). Molecular markers are valuable tools that can be used to study olive genetics, and have been applied to the identification of cultivars.

For instance, ISSR and SSR markers were used to analyze 41 olive cultivars and resulted in an efficient distinction of each accession (Gomes et al., 2009). Ganino et al. (2007) identified ancient cultivars in the Emilia region, Northern Italy, and revealed a large amount of genetic diversity among their sample of 109 cultivars. Belaj et al. (2004) used RAPD and AFLP markers and effectively revealed intra-cultivar variability, and distinguished individuals obtained by clonal selection of the olive varieties 'Arbequina' and 'Manzanilla de Sevilla'. Genetic analyses have also allowed the study of the olive domestication and the identification of several cultivated genetic pools in the Mediterranean basin (Belaj et al., 2012; Besnard et al., 2013).

The history of olive introduction and cultivation in China is recent and little research has focused on this species, especially with regard to genetic diversity and germplasm resources. Statistical analysis has shown that olive oil imports in six months of the 2012/2013 crop year (October 2012-March 2013) rose by 17\% in China, reaching a total of 22,640.9 $\mathrm{t}$ (IOC). So far, China has introduced a large number of olive cultivars, and the main varieties are Arbequina, Mixaj, Frantoio, Leccino, Kokermadh I Berat, and Picual. Therefore, the study of genetic relationships is important for olive breeding and production. The olive cultivars grown in China have been recently studied with RAPD, SSR, and ISSR genetic markers (Qiu et al., 2008; Chen et al., 2013), but the genetic relationships between introduced and local cultivars were not investigated. Moreover, the number of cultivars investigated in these studies was limited. Many Chinese cultivars were cloned from seedling selection or cross-breeding according to introduced cultivars ( $\mathrm{Li}$ and $\mathrm{Yu}, 2012$ ). This shows that Chinese domesticated breeding and 
introduced cultivars have common genetic backgrounds. However, Chinese breeding cultivars are influenced by the external environment and are grown in different areas in China. Therefore, these cultivars have rich genetic diversity, and more synonymy or homonymy were found in Chinese breeding cultivars.

The aim of this study was to evaluate the genetic relationships of 32 olive cultivars grown in Xichang using a combination of SSR and ISSR, and to assess the reliability of these two marker types in combination.

\section{MATERIAL AND METHODS}

\section{Plant materials}

Thirty-two olive varieties were collected from Sichuan Liang Shan New Technology Development Co., Ltd. in China (Table 1) and leaves were stored at $-70^{\circ} \mathrm{C}$. The samples included five Chinese breeding cultivars (Table 2), 'Ezhi', 'Zhongsan 24', 'Chenggu 32', 'Yun Tai 14', and 'Zhang Lin', and 27 introduced cultivars (Figure 1).

Table 1. List of the 32 olive cultivars analyzed, country of origin, and use $(\mathrm{O}=$ oil; $\mathrm{T}=$ table olive; $\mathrm{O} / \mathrm{T}=$ oil and table olive) of fruits.

\begin{tabular}{|c|c|c|c|c|c|c|c|}
\hline Code & Cultivar & Country of origin & Use & Code & Cultivar & Country of origin & Use \\
\hline 1 & Megaritiki & Greece & $\mathrm{O} / \mathrm{T}$ & 17 & Barnea & Israel & $\mathrm{O}$ \\
\hline 2 & Mixaj Pegenit & Albania & $\mathrm{O}$ & 18 & Tanche & France & $\mathrm{O} / \mathrm{T}$ \\
\hline 3 & Leccino & Italy & $\mathrm{O}$ & 19 & Bardhe I Krauje & Albania & $\mathrm{O}$ \\
\hline 4 & Kalamata & Greece & $\mathrm{T}$ & 20 & Ottobratica & Italy & $\mathrm{O}$ \\
\hline 5 & Picual & Spain & $\mathrm{O}$ & 21 & Chenggu 32 & China & $\mathrm{O} / \mathrm{T}$ \\
\hline 6 & Ezhi & China & $\mathrm{O}$ & 22 & Yun Tai 14 & China & $\mathrm{O} / \mathrm{T}$ \\
\hline 7 & Koroneiki & Greece & $\mathrm{O}$ & 23 & Greece 3\# & Greece & $\mathrm{O}$ \\
\hline 8 & Frantoio & Italy & $\mathrm{O}$ & 24 & Pendoline & Italy & $\mathrm{O}$ \\
\hline 9 & Kanine & Albania & $\mathrm{O} / \mathrm{T}$ & 25 & Zhang Lin & China & $\mathrm{O} / \mathrm{T}$ \\
\hline 10 & Arbequina & Spain & $\mathrm{O}$ & 26 & Coratina & Italy & $\mathrm{O}$ \\
\hline 11 & Lianolia Kerkeyras & Greece & $\mathrm{O}$ & 27 & Manzanillo & Israel & $\mathrm{O} / \mathrm{T}$ \\
\hline 12 & Ascolana Tenera & Italy & $\mathrm{T}$ & 28 & Mixaj I Dukat & Albania & $\mathrm{O}$ \\
\hline 13 & Zhongsan 24 & China & $\mathrm{O} / \mathrm{T}$ & 29 & Mixaj & Albania & $\mathrm{O}$ \\
\hline 14 & Kokermadh I Berat & Albania & $\mathrm{T}$ & 30 & Nisjot & Albania & $\mathrm{O}$ \\
\hline 15 & Chemlali & Tunisia & $\mathrm{O}$ & 31 & Manaki & Greece & $\mathrm{O}$ \\
\hline 16 & Frantoio A. Corsini & Italy & $\mathrm{O}$ & 32 & Kalinjot & Albania & $\mathrm{O} / \mathrm{T}$ \\
\hline
\end{tabular}

Cultivars synonyms according to the FAO's database; five samples ('Ezhi', 'Zhongsan 24', 'Chenggu 32', 'Yun Tai 14 ', 'Zhang Lin') are issued from a Chinese breeding program.

Table 2. Origin of olive cultivars bred in China.

\begin{tabular}{lll}
\hline Cultivar & Origin & Breeding unit and time \\
\hline Ezhi & Former Soviet Union seedlings from & Wuhan Botany Institute, Chinese \\
Zhongsan 24 & Nikitsky Botanical Garden & Academy of Sciences (1976) \\
Yun Tai 14 & Fromer Soviet Union Ascolana & Institute of Botany, Jiangsu Province and \\
& Tenera seedlings & Chinese Academy of Sciences (1966) \\
Chenggu 32 & Nikitskii II seedlings & Institute of Botany, Jiangsu Province and \\
& Chinese Academy of Sciences (1979) \\
Zhanglin & Coligno seedlings & Foresty Bureau of Chenggu Country, \\
\hline
\end{tabular}




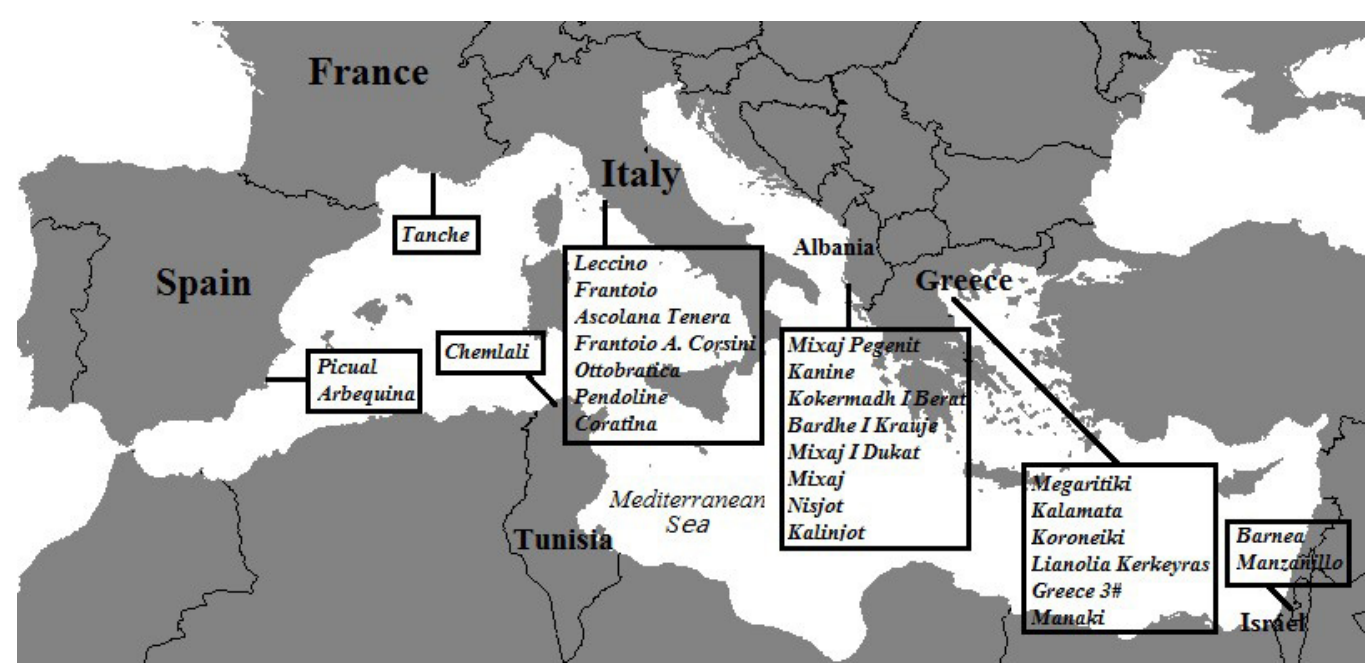

Figure 1. Map of the origin countries of the introduced olive cultivars used in this study.

\section{DNA extraction}

Total genomic DNA was extracted from young olive leaves using the modified CTAB method (Saghai-Maroof et al., 1984). The isolated DNA was dissolved in $100-\mu \mathrm{L}$ of TE buffer (10 mM Tris-HCl, $\mathrm{pH} 8.0 ; 1 \mathrm{mM}$ EDTA, $\mathrm{pH} 8.0)$ and $5-\mu \mathrm{L}$ RNase $(10 \mathrm{mg} / \mathrm{mL})$ was added. The genomic DNA was stored at $-20^{\circ} \mathrm{C}$ for SSR and ISSR assays.

\section{SSR analysis}

Thirteen pairs of SSR markers (Table 3) were selected among the microsatellite sets that have been previously described GAPU (Carriero et al., 2002), UDO (Cipriani et al., 2002), DCA (Sefc et al., 2000). Screening was based on the level of polymorphism and the availability of genetic profiles.

SSR-PCR has been previously described in detail (Rallo et al., 2000). Amplification was performed using a Bio-Rad S1000 ${ }^{\mathrm{TM}}$ Thermal cycler (USA) in a $25-\mu \mathrm{L}$ volume mixture with $2.5 \mu \mathrm{L}$ 10X PCR buffer, $0.2-\mathrm{mM}$ dNTPs, $2.5-\mathrm{mM} \mathrm{MgCl}_{2}, 0.2-\mu \mathrm{M}$ primer (Invitrogen ${ }^{\mathrm{TM}}$, China), 30-ng genomic DNA and 1-U Taq DNA polymerase (Tiangen, ET101). The PCR steps included an initial denaturation for $5 \mathrm{~min}$ at $94^{\circ} \mathrm{C} ; 30$ cycles of $30 \mathrm{~s}$ at $94^{\circ} \mathrm{C}, 30 \mathrm{~s}$ at the annealing temperature primer pair dependent (Table 3 ); and $40 \mathrm{~s}$ at $72^{\circ} \mathrm{C}$; the program was completed by a 5 -min extension at $72^{\circ} \mathrm{C}$.

The PCR amplification products were visualized following electrophoresis in a $3 \%$ agarose gel in 1X TBE buffer at $80 \mathrm{~V}$ for $50 \mathrm{~min}$. Next, amplification products were separated by $8 \%$ polyacrylamide gel electrophoresis, in $0.5 \mathrm{X}$ TBE buffer at $120 \mathrm{~V}$ for $2 \mathrm{~h}$. Finally, silver staining (Caetano-Anollés and Gresshoff, 1994) was performed with some modifications. The pBR322 DNA MspI (Tiangen, MD206) was used as a standard DNA molecular weight marker. Gels were photographed under UV light using the Gel Doc ${ }^{\mathrm{TM}}$ EZ System (Bio-Rad) and the images were analyzed using Image $\mathrm{Lab}^{\mathrm{TM}}$ 3.0. 


\section{ISSR analysis}

The ISSR-PCR mixture reaction and conditions were based on a study by Martins-Lopes et al. (2007). Twelve ISSR primer sets, published by the University of British Columbia Laboratory, and nine primers (Table 4 ) were used for test analyses. The amplification reaction was carried out in a $25-\mu \mathrm{L}$ volume containing 50-ng DNA, 2.5- $\mu \mathrm{L}$ 10X PCR buffer, $0.2-\mathrm{mM}$ dNTPs, $2.5-\mathrm{mM}$ $\mathrm{MgCl}_{2}, 0.15-\mu \mathrm{M}$ primer (Invitrogen ${ }^{\mathrm{TM}}$, China) and 1-U Taq DNA polymerase (Tiangen, ET101). The PCR reaction steps comprised an initial denaturation step for $5 \mathrm{~min}$ at $94^{\circ} \mathrm{C} ; 35$ cycles of $35 \mathrm{~s}$ at $94^{\circ} \mathrm{C}, 50 \mathrm{~s}$ at the primer annealing temperature (Table 4), and $1 \mathrm{~min}$ at $72^{\circ} \mathrm{C}$; with a final 5-min extension at $72^{\circ} \mathrm{C}$. Afterwards, amplified products were separated by electrophoresis in $2 \%$ agarose gel in TBE buffer at $100 \mathrm{~V}$ for $50 \mathrm{~min}$ and photographed under UV light.

Table 3. Thirten microsatellite loci used in our study. For each locus, the primer sequences, annealing temperature $(\mathrm{Ta})$, number of alleles, observed heterozygosity $\left(H_{\mathrm{O}}\right)$, expected heterozygosity $\left(H_{\mathrm{E}}\right)$, null allele frequency (Null), and polymorphism information content (PIC) are given.

\begin{tabular}{|c|c|c|c|c|c|c|c|}
\hline Locus & Primer sequence $\left(5^{\prime} \rightarrow 3^{\prime}\right)$ & $\mathrm{Ta}\left({ }^{\circ} \mathrm{C}\right)$ & No. alleles & $H_{\mathrm{O}}$ & $H_{\mathrm{E}}$ & Null & PIC \\
\hline \multirow[t]{2}{*}{ GAPU47 } & F: GATCAGCTTAGTCTCATATTCTCTCTC & & & & & & \\
\hline & R: CCTCGACTGATTTACACACCA & 54.5 & 6 & 0.990 & 0.919 & -0.0404 & 0.908 \\
\hline \multirow[t]{2}{*}{ GAPU59 } & F: CCCTGCTTTGGTCTTGCTAA & & & & & & \\
\hline & R: CAAAGGTGCACTTTCTCTCG & 48.9 & 6 & 0.935 & 0.902 & -0.0203 & 0.889 \\
\hline \multirow[t]{2}{*}{ GAPU89 } & F: GATCATTCCACACACGAGAG & & & & & & \\
\hline & R: AACACATGCCCACAAACTGA & 43.9 & 9 & 0.943 & 0.902 & -0.0258 & 0.889 \\
\hline \multirow[t]{2}{*}{ GAPU101 } & F: CATGAAAGGAGGGGGACATA & & & & & & \\
\hline & R: GGCACTTGTTGTGCAGATTG & 53.3 & 7 & 0.905 & 0.918 & 0.0048 & 0.907 \\
\hline \multirow[t]{2}{*}{ GAPU103A } & F: TGAATTTAACTTTAAACCCACACA & & & & & & \\
\hline & R: GCATCGCTCGATTTTTATCC & 49.4 & 10 & 0.960 & 0.940 & -0.0115 & 0.934 \\
\hline \multirow[t]{2}{*}{ UDO99-09 } & F: TTGATTTCACATTGCTGACCA & & & & & & \\
\hline & R: CATAGGGAAGAGCTGCAAGG & 46.3 & 12 & 0.951 & 0.899 & -0.0307 & 0.885 \\
\hline \multirow[t]{2}{*}{ UDO99-011 } & F: TGACTCCCTTTAAACTCATCAGG & & & & & & \\
\hline & R:TGCGCATGTAGATGTGAATATG & 49.4 & 7 & 0.958 & 0.927 & -0.0188 & 0.918 \\
\hline \multirow[t]{2}{*}{ UDO99-043 } & F: TCGGCTTTACAACCCATTTC & & & & & & \\
\hline & R: TGCCAATTATGGGGCTAACT & 49.4 & 12 & 0.947 & 0.915 & -0.0181 & 0.906 \\
\hline \multirow[t]{2}{*}{ DCA03 } & F: CCCAAGCGGAGGTGTATATTGTTAC & & & & & & \\
\hline & R: TGCTTTTGTCGTGTTTGAGATGTTG & 51.3 & 9 & 0.785 & 0.782 & -0.1737 & 0.768 \\
\hline \multirow[t]{2}{*}{ DCA09 } & F: AATCAAAGTCTTCCTTCTCATTTCG & & & & & & \\
\hline & R: GATCCTTCCAAAAGTATAACCTCTC & 56 & 8 & 0.944 & 0.935 & -0.0066 & 0.926 \\
\hline \multirow[t]{2}{*}{ DCA10 } & F: CGTGACCACCTAAATCCGCCCC & & & & & & \\
\hline & R: CTGTCCAGAGCTAAAGGTTTCG & 53.9 & 9 & 0.945 & 0.905 & -0.0248 & 0.893 \\
\hline \multirow[t]{2}{*}{ DCA16 } & F: TTAGGTGGGATTCTGTAGATGGTTG & & & & & & \\
\hline & R: TTTTAGGTGAGTTCATAGAATTAGC & 51.3 & 9 & 0.919 & 0.906 & -0.0095 & 0.894 \\
\hline \multirow[t]{2}{*}{ DCA18 } & F:AAGAAAGAAAAAGGCAGAATTAAGC & & & & & & \\
\hline & F:AAGAAAGAAAAAGGCAGAATTAAGC & 55 & 3 & 0.964 & 0.914 & -0.0301 & 0.904 \\
\hline
\end{tabular}

Table 4. Description of ISSR primers used in this study: primer sequence, annealing temperature (Ta), number of alleles, number of genotypes, and \% polymorphism.

\begin{tabular}{|c|c|c|c|c|c|}
\hline Primer & Primer sequence $\left(5^{\prime} \rightarrow 3^{\prime}\right)$ & $\mathrm{Ta}\left({ }^{\circ} \mathrm{C}\right)$ & No. alleles & No. genotypes & $\%$ Polymorphism \\
\hline UBC807 & $(\mathrm{AG})_{8} \mathrm{~T}$ & 56.5 & 11 & 12 & 92 \\
\hline UBC 809 & $(\mathrm{AG})_{8} \mathrm{G}$ & 55.1 & 11 & 13 & 85 \\
\hline UBC 810 & $(\mathrm{GA})_{8}^{\circ} \mathrm{T}$ & 51.9 & 7 & 7 & 100 \\
\hline UBC 811 & $(\mathrm{GA})_{8}^{8} \mathrm{G}$ & 55.1 & 11 & 11 & 100 \\
\hline UBC 815 & $(\mathrm{CT})_{8} \mathrm{G}$ & 51.4 & 7 & 7 & 100 \\
\hline UBC 823 & $(\mathrm{TC})_{8}^{\circ} \mathrm{C}$ & 53.1 & 9 & 9 & 100 \\
\hline UBC 825 & $(\mathrm{AC})_{8}^{8} \mathrm{~T}$ & 52.6 & 7 & 8 & 88 \\
\hline UBC 834 & $(\mathrm{AG})_{8}^{8} \mathrm{CT}$ & 56.4 & 9 & 11 & 82 \\
\hline UBC 880 & $(\text { GGAGA })_{3}$ & 52.5 & 6 & 7 & 86 \\
\hline
\end{tabular}




\section{Data analysis}

For SSRs and ISSRs, polymorphic fragments were scored as (1) for their presence and (0) for their absence. All ISSR bands not clearly identified were discarded. Genotypes of the 32 cultivars were analyzed according to the similarity matrix using the available alleles (Nei and $\mathrm{Li}, 1979$ ). Cluster analysis of genetic similarity was studied by constructing dendrograms via the unweighted pair-group method with arithmetic averages (UPGMA) using NTSYS-pc ver. 2.10e (Roiilf, 2000). SSR data were also used to estimate the observed heterozygosity $\left(H_{\mathrm{O}}\right)$, expected heterozygosity $\left(H_{\mathrm{E}}\right)$, and polymorphism information content (PIC) using CERVUS 3.0.3 (Kalinowski et al., 2007).

$$
P I C=1-\sum_{i=1}^{n} P_{i}^{2}
$$

where $P_{i}$ is the allele frequency and $n$ is the number of alleles.

\section{RESULTS}

\section{SSR polymorphism}

In our study, the 13 SSR loci provide a total of 107 alleles from the 32 olive samples. The average of number alleles per primer was 8.6 (Table 3 ). In the whole sample, the average observed and expected heterozygosities $\left(H_{\mathrm{O}}\right.$ and $\left.H_{\mathrm{E}}\right)$ based on SSRs was identical (0.934). PIC values ranged from 0.768 for DCA03 to 0.934 for GAPU103A, with an average of 0.894 .

\section{ISSR polymorphism}

A total of 78 ISSR amplified polymorphic bands were identified using nine primers. The number of polymorphic bands per primer ranged from six for UBC880 to 11 for UBC 807, UBC809, UBC811, and UBC834 (Table 4); all the bands ranged from 250 to 2,400 bp. The bands amplified by primer UBC 825 are shown in Figure 2. The percentage of polymorphic bands ranged from 82 to $100 \%$, with an average of $91.8 \%$. We found that all cultivars could be distinguished using only two ISSR primers: UBC809 and UBC811.

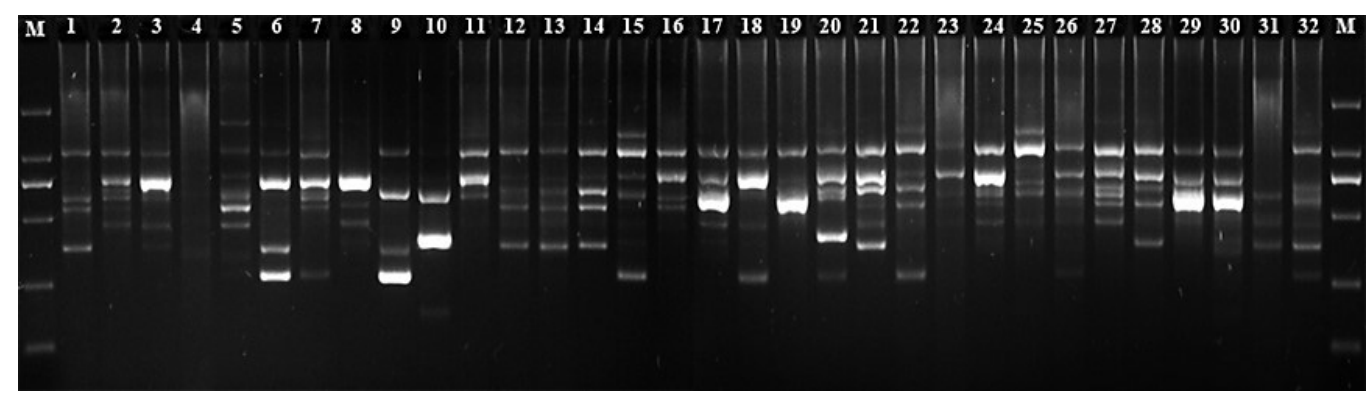

Figure 2. ISSR-PCR products from 32 olive cultivars (Table 1) analyzed with primer UBC825. Lane $M=$ D2000 DNA marker (TIANGEN). 


\section{Combination of SSRs and ISSRs to investigate genotype relationships}

SSR and ISSR technology were combined to assess the genetic relationship between 32 olive cultivars. A dendrogram based on SSR and ISSR markers (107 SSR alleles and 78 ISSR fragments) was reconstructed with the similarity coefficient and the UPGMA algorithm (Figure 3). This dendrogram showed cultivars with a similarity coefficient ranging from 0.57 to 0.83 . The lowest GS (genetic similarity) coefficient of 0.58 was obtained between the two cultivars 'Kalamata' and 'Kalinjot', and the highest GS coefficient of 0.83 was observed between the two cultivars 'Pendoline' and 'Greece 3\#'.

All cultivars were clustered into six groups, and one independent branch 'Coratina' was observed. Group I contained 13 cultivars, with three local ('Zhongsan 24', 'Chenggu 32', and 'Yun Tai 14') and nine foreign cultivars. 'Zhongsan 24' and 'Ascolanatenera' (GS = 0.77) having the similar fruit weight $(>6.13 \mathrm{~g}$, Table 5$)$ and oil content (>18\%). Two Mixaj type 'Mixaj' and 'Mixaj I Dukat' were clustered together.

Group II comprised nine cultivars, which were clustered into two sub-groups. The first sub-group contained four cultivars ('Koroneiki', 'Kanine', 'Lianolia Kerkeyr' and 'Chemlai'), while the second sub-group contained five cultivars ('Frantoio', 'Greece 3\#', 'Pendoline', 'Tance', and 'Zhang Lin'). 'Greece 3\#' and 'Pendoline' were clustered into one group with a high GS of 0.94; these cultivars produce small fruits (1.5-2.0 g).

Group IV clustered two cultivars ('Arbequina' and 'Barnea') with a high oil content $(>10 \%)$. The last group (group VI) clustered two cultivars 'Kalamata' and 'Kalinjot' with a common origin, but the genetic similarity of 0.58 was low and deviated from the main groups. One independent branch 'Coratina' is rarely planted in local olive plantations.

The principal coordinates analysis could also determine genetic relationships between 32 olive cultivars from 2 or 3-dimensional space. The genotypic diversity of all olive cultivars was analyzed using PCoA-3D based SSR and ISSR data, which is shown in Figure 4.

The PCA of dim-1, 2, and 3 are the first, second, and third principal coordinates which explain $20.8 \%$ of the total variation, comprising $8.3,6.7$, and $5.8 \%$ each respectively. The principal coordinate analysis provided clearer groups compared with UPGMA, and the result were clustered into three groups. 'Leccion', 'Picual', and 'Ezhi' were clustered into a small group and 'Kalamata' and 'Kalinjot' comprised another small group. Only one cultivar, 'Manaki' was separated from the three main groups.

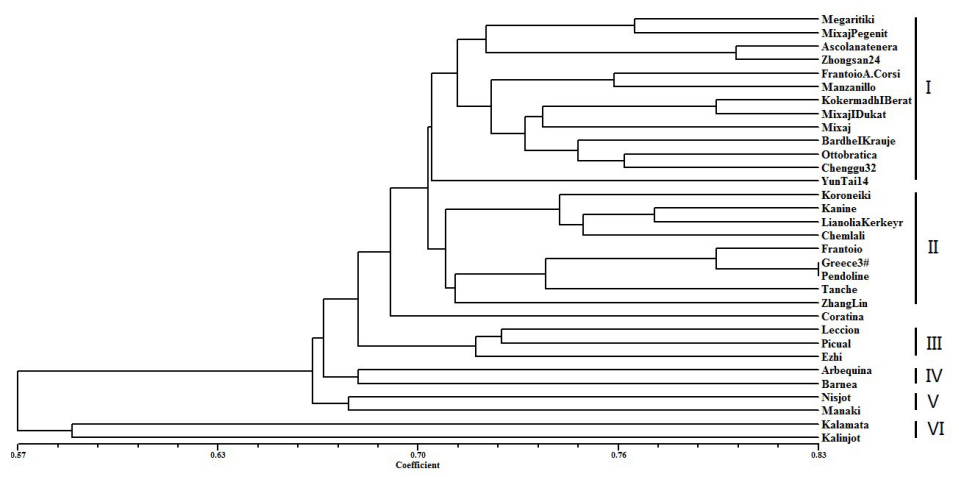

Figure 3. Dendrogram cluster analysis of 32 olive cultivars with similarity coefficient and unweighted pair group method with arithmetic (UPGMA) using SSR and ISSR primers. 
Table 5. Morphological characteristics of 32 olive cultivars.

\begin{tabular}{|c|c|c|c|c|c|c|}
\hline Cultivar name & Oil content $t^{\mathrm{a}}$ & Fruit weight ${ }^{\mathrm{b}}$ & Sarcocarp/stone ${ }^{c}$ & Weight of 100 leaves $^{d}$ & Leaf shape ${ }^{e}$ & Leaf curly shape ${ }^{f}$ \\
\hline Megaritiki & M & $\mathrm{H}$ & $\mathrm{H}$ & M & EP-LA & FL \\
\hline Mixaj Pegenit & M & $\mathrm{H}$ & $\mathrm{H}$ & $\mathrm{L}$ & LA & EP \\
\hline Leccino & $\mathrm{H}$ & $\mathrm{H}$ & $\mathrm{H}$ & M & EP-LA & FL \\
\hline Kalamata & $\mathrm{H}$ & M & $\mathrm{H}$ & VH & LA & FL \\
\hline Picual & $\mathrm{H}$ & VH & VH & M & LA & FL \\
\hline Ezhi & $\mathrm{H}$ & $\mathrm{H}$ & $\mathrm{H}$ & M & EP-LA & $\mathrm{HE}$ \\
\hline Koroneiki & $\mathrm{H}$ & $\mathrm{L}$ & $\mathrm{H}$ & $\mathrm{L}$ & EP-LA & FL \\
\hline Frantoio & $\mathrm{H}$ & M & $\mathrm{H}$ & M & EP-LA & FL \\
\hline Kanine & $\mathrm{L}$ & VH & M & $\mathrm{H}$ & LA & FL \\
\hline Arbequina & $\mathrm{M}$ & $\mathrm{M}$ & $\mathrm{H}$ & M & LA & $\mathrm{EP}$ \\
\hline Lianolia Kerkeyras & $\mathrm{H}$ & M & $\mathrm{H}$ & $\mathrm{L}$ & EP-LA & FL \\
\hline Ascolana Tenera & VH & VH & $\mathrm{H}$ & $\mathrm{H}$ & LA & $\mathrm{EP}$ \\
\hline Zhongsan 24 & VH & VH & $\mathrm{H}$ & $\mathrm{VH}$ & LA & EP \\
\hline Kokermadh I Berat & $\mathrm{H}$ & $\mathrm{VH}$ & $\mathrm{H}$ & M & LA & $\mathrm{HE}$ \\
\hline Chemlali & $\mathrm{H}$ & $\mathrm{M}$ & $\mathrm{H}$ & $\mathrm{H}$ & EP-LA & EP \\
\hline Frantoio A. Corsini & M & M & $\mathrm{H}$ & M & EP-LA & FL \\
\hline Barnea & M & M & $\mathrm{H}$ & $\mathrm{H}$ & EP-LA & FL \\
\hline Tanche & M & M & VH & M & EP-LA & HP \\
\hline Bardhe I Krauje & $\mathrm{H}$ & M & $\mathrm{H}$ & M & LA & FL \\
\hline Ottobratica & M & M & $\mathrm{H}$ & M & EP-LA & FL \\
\hline Chenggu 32 & $\mathrm{H}$ & $\mathrm{H}$ & $\mathrm{M}$ & M & EP-LA & FL \\
\hline Yun Tai 14 & VH & $\mathrm{H}$ & $\mathrm{H}$ & $\mathrm{M}$ & EP-LA & FL \\
\hline Greece 3\# & $\mathrm{H}$ & $M$ & $\mathrm{H}$ & $\mathrm{H}$ & LA & FL \\
\hline Pendoline & M & M & $\mathrm{H}$ & M & LA & FL \\
\hline Zhang Lin & $\mathrm{L}$ & $\mathrm{L}$ & M & M & LA & $\mathrm{HP}$ \\
\hline Coratina & $\mathrm{H}$ & $\mathrm{H}$ & $\mathrm{H}$ & $\mathrm{H}$ & LA & FL \\
\hline Manzanillo & M & $\mathrm{H}$ & $\mathrm{H}$ & M & LA & FL \\
\hline Mixaj I Dukat & $\mathrm{H}$ & $\mathrm{M}$ & $\mathrm{H}$ & M & EP-LA & $\mathrm{EP}$ \\
\hline Mixaj & $\mathrm{H}$ & $\mathrm{H}$ & $\mathrm{H}$ & M & EP-LA & $\mathrm{EP}$ \\
\hline Nisjot & $\mathrm{H}$ & M & $\mathrm{H}$ & M & EP-LA & FL \\
\hline Manaki & VH & M & $\mathrm{H}$ & $\mathrm{H}$ & LA & FL \\
\hline Kalinjot & VH & $\mathrm{H}$ & $\mathrm{H}$ & $\mathrm{H}$ & EP-LA & $\mathrm{EP}$ \\
\hline
\end{tabular}

${ }^{\mathrm{a}}$ Oil content: low $=\mathrm{L}($ less than $10 \%) ;$ medium $=\mathrm{M}(10 \%$ to $15 \%)$; high $=\mathrm{H}(15 \%$ to $20 \%)$; very high $=\mathrm{VH}$ (greater

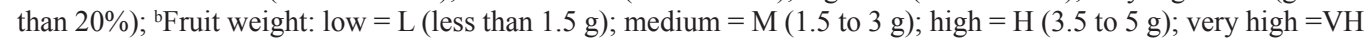

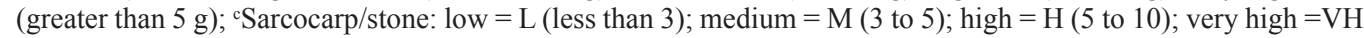
(greater than 10); ${ }^{d}$ Weight of 100 leaves: low $=\mathrm{L}$ (5 to $\left.10 \mathrm{~g}\right)$; medium $=\mathrm{M}$ (10 to $\left.15 \mathrm{~g}\right)$; high $=\mathrm{H}$ (15 to $20 \mathrm{~g}$ ); very high $=\mathrm{VH}$ (greater than $20 \mathrm{~g}$ ); ${ }^{\mathrm{e}}$ Leaf shape: elliptic-lanceolate $=\mathrm{EP}-\mathrm{LA}$; lanceolate $=\mathrm{LA}$; ${ }^{\mathrm{f}}$ Leaf curly shape: hyponasty $=$ HP; Flat $=$ FL; Epinasty $=$ EP; Helicoidal $=$ HE

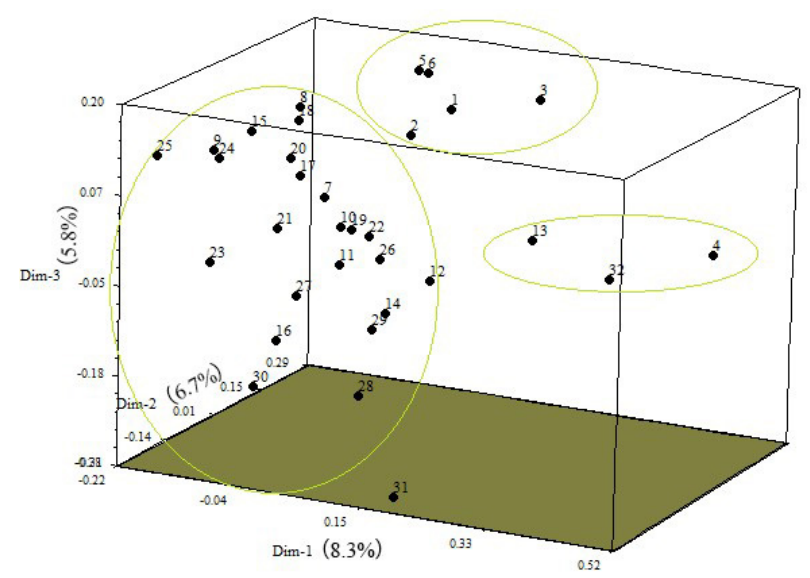

Figure 4. Principal coordinate analysis of 32 olive cultivars (Table 1) based on SSR and ISSR data. 


\section{DISCUSSION}

\section{Discriminatory power of SSR and ISSR}

SSR and ISSR marker systems were combined in this study and showed that the high polymorphism rate (Tables 3 and 4) is consistent with the results from previous reports on olive genetic diversity based on different molecular markers (Gomes et al., 2009; Souza et al., 2012; Abdelhamid et al., 2013; Asadiar et al., 2013; Trujillo et al., 2014). These results were tested repeatedly in different laboratories and showed stable results. This phenomenon clearly demonstrated that there is great diversity within in the olive germplasm introduced to China.

The SSR marker loci developed in olive (Rallo et al., 2000; Sefc et al., 2000; Carriero et al., 2002; Cipriani et al., 2002; De la Rosa et al., 2002; Díaz et al., 2006) were used to genotype olive cultivars.

PIC values estimate the discriminatory capacity of a marker. The average PIC value for SSR loci was 0.894 and the 32 olive cultivar PIC values ranged from 0.786 in DCA03 to 0.934 in GAPU103A. According to statistical analysis, all 13 loci PIC values were superior to 0.75 , which was similar to the PIC value $(0.863)$ reported in olive cultivars by Gomes et al. (2009). The present study also revealed higher values of $H_{\mathrm{E}}(0.905)$ and $H_{\mathrm{O}}(0.934)$ than those reported in the literature (Muzzalupo et al., 2010; Trujillo et al., 2014). One of the aims of this study was to determine loci with the power to distinguish between genotypes. In our study, the discrimination power (PD) values were greater than 0.57 . However, we found that locus DCA03 has the lowest values for $H_{\mathrm{E}}(0.785), H_{\mathrm{O}}(0.782)$, and PIC $(0.768)$, with similar results obtained by Sefc et al. (2000); this might indicate a genotype problem (Ben-Ayed et al., 2014).

Of the nine ISSR primers tested, $91.8 \%$ of polymorphic fragments were observed. In the present study, all olive cultivars could be distinguished using only two ISSR primers: UBC809 and UBC811. The high efficiency of ISSR markers to identify cultivars has been previously reported in the genetic diversity of olive cultivars (Essadki et al., 2006; El Saied et al., 2012). The genetic similarity coefficient represents the richness of genetic diversity among olive varieties. Belaj et al. (2003) obtained genetic similarity coefficients for three types of markers. They showed that SSRs $(\mathrm{GS}=0.36)$ are more efficient at distinguishing cultivated olive genotype than are AFLPs (0.56) and RAPDs (0.86). On the contrary, the discriminating capacity was SSR $>$ AFLP $>$ RAPD, and a similar result was reported for the discriminating capacity, SSR > ISSR. In our study, the GS was SSR (0.695) < ISSR (0.710) and the discrimination ability was SSR > ISSR.

\section{Genetic relationships between olive cultivars}

In the present study, 32 olive cultivars were clustered using similarity coefficients, and the unweighted pair group method arithmetic (UPGMA) observed similar results to those obtained by the PCA analysis. Two cultivars 'Ascolanatenera' and 'Zhong san 24' had very similar morphology, all of which have very heavy fruit $(>6.13 \mathrm{~g})$ and high fruit oil content $(>18 \%)$. Moreover, 'Zhong san 24' was bred from seedling populations of 'Ascolanatenera' seeds. 'Greece 3\#' and 'Pendoline' have high GS (0.83) in the cluster analysis. As we know, 'Greece 3\#' and 'Pendoline' produce small fruits (1.5-2.0 g), but these trees could be used to pollinate new olive gardens. According to the survey, 'Pendoline' is widely distributed in local olive plantations. It revealed the high frequency of hybrids between olive cultivars. The cul- 
tivar 'Mixaj' was introduced in China in the 1960s from Albania and has produced a number of subspecies (Gómez-del-Campo and Connor, 2011). In the present study, 'Mixaj Pegenit' and 'Mixaj I Dukat' are two types of 'Mixaj', and the 'Mixaj'-'Mixaj I Dukat' were clustered together having similar genetic and morphological traits.

So far, China has introduced a large number of foreign olive cultivars from the Mediterranean region. Therefore, we have found high genetic diversity in our study because of the differences between native and introduced olive species grown in China. These species could not avoid the influence of the environment and some cultivars may have experienced selfbreeding and cross-breeding (Martins-Lopes et al., 2007).

Selection of seeding breeding is in an important way to improve olive varieties. In recent years, China has made great progress in seeding breeding. Therefore, China olive cultivars were clustered into different groups in cluster analysis. In General, some introduced cultivars cannot be clustered according to their geographical origin, but based on morphological characteristics such as use, oil content, and fruit weight.

At present, Spanish and Italian groups have established the World Olive Germplasm Bank (WOGB) and "CRA-Olive Growing And Oil Industry Research Center" (CRA-OLI) (Bracci et al., 2011; Díez et al., 2012). We hope that the olive genetic resource can promote better protection and development.

In conclusion, the SSR and ISSR markers were reliable for the analysis of genetic relationships between these olive cultivars. The olive genotypes were evaluated according to the data, and showed that olive cultivars cultivated in China harbor high genetic diversity. Our results demonstrate the higher discriminating capacity of SSRs compared to ISSRs. This study enriches the available olive genetic resources and promotes the progression of olive breeding.

\section{ACKNOWLEDGMENTS}

Research supported by the Technology Program of Sichuan Provincial Science and Technology Department (\#12ZC2220) and we thank Liang Shan Zhong Ze New Technology Development Co., Ltd., for providing the olive materials.

\section{REFERENCES}

Abdelhamid S, Grati-kamoun N, Marra F and Caruso T (2013). Genetic similarity among Tunisian cultivated olive estimated through SSR markers. Sci. Agric. 70: 33-38.

Asadiar LS, Rahmani F and Siami A (2013). Assessment of genetic diversity in the Russian olive (Elaeagnus angustifolia) based on ISSR genetic markers. Rev. Ciênc. Agro. 44: 310-316.

Bandelj D, Jakše J and Javornik B (2004). Assessment of genetic variability of olive varieties by microsatellite and AFLP markers. Euphytica. 136: 93-102.

Belaj A, Satovic Z, Cipriani G, Baldoni L, et al. (2003). Comparative study of the discriminating capacity of RAPD, AFLP and SSR markers and of their effectiveness in establishing genetic relationships in olive. Theor. Appl. Genet. 107: 736-744.

Belaj A, Rallo L, Trujillo I and Baldoni L (2004). Using RAPD and AFLP markers to distinguish individuals obtained by clonal selection of Arbequina' and Manzanilla de Sevilla' Olive. Hort. Sci. 39: 1566-1570.

Belaj A, del Carmen Dominguez-García M, Atienza SG, Urdíroz NM, et al. (2012). Developing a core collection of olive (Olea europaea L.) based on molecular markers (DArTs, SSRs, SNPs) and agronomic traits. Tree Genetics \& Genomes. 8: 365-378.

Ben-Ayed R, Sans-Grout C, Moreau F, Grati-Kamoun N, et al. (2014). Genetic similarity among Tunisian olive cultivars and two unknown feral olive trees estimated through SSR markers. Bioch. genet. 1-11.

Besnard G, El Bakkali A, Haouane H, Baali-Cherif D, et al. (2013). Population genetics of Mediterranean and Saharan olives: 
geographic patterns of differentiation and evidence for early generations of admixture. Annals of botany. 112: 1293-1302.

Bracci T, Busconi M, Fogher C and Sebastiani L (2011). Molecular studies in olive (Olea europaea L.): overview on DNA markers applications and recent advances in genome analysis. Plant cell reports. 30: 449-462.

Breton C, Médail F, Pinatel C and Bervillé A (2006). De l'olivier à l'oléastre: origine et domestication de l'Olea europaea L. dans le Bassin méditerranéen. Cahiers Agric. 15: 329-336.

Caetano-Anollés G and Gresshoff PM (1994). Staining nucleic acids with silver: an alternative to radioisotopic and fluorescent labeling. Prom. Notes Magazine. 45: 13-18.

Carriero F, Fontanazza G, Cellini F and Giorio G (2002). Identification of simple sequence repeats (SSRs) in olive (Olea europaea L.). Theor. Appl. Genet. 104: 301-307.

Chen YH, Ning DL, Li YJ, Wu T, et al. (2013). Molecular Identification among 59 Olive Cultivars Based on ISSR Markers. J. Nourt. Forest. Univ. 41: 13-17.

Cipriani G, Marrazzo M, Marconi R, Cimato A, et al. (2002). Microsatellite markers isolated in olive (Olea europaea L.) are suitable for individual fingerprinting and reveal polymorphism within ancient cultivars. Theor. Appl. Genet. 104: 223-228.

Díaz A, De la Rosa R, Martín A and Rallo P (2006). Development, characterization and inheritance of new microsatellites in olive (Olea europaea L.) and evaluation of their usefulness in cultivar identification and genetic relationship studies. Tree Genet. Genomes. 2: 165-175.

Díez CM, Imperato A, Rallo L, Barranco D, et al. (2012). Worldwide core collection of olive cultivars based on simple sequence repeat and morphological markers. Crop Sci. 52: 211-221.

De la Rosa R, James C and Tobutt K (2002). Isolation and characterization of polymorphic microsatellites in olive (Olea europaea L.) and their transferability to other genera in the Oleaceae. Mol. Ecol. Notes. 2: 265-267.

El Saied SH, Hegazi AA, Tawfik AA and Sayed HA (2012). Molecular characterization of local and imported olive cultivars grown in Egypt using ISSR technique. J. Hort. Sci. 4: 148-154.

Erre P, Chessa I, Muñoz-Diez C, Belaj A, et al. (2010). Genetic diversity and relationships between wild and cultivated olives (Olea europaea L.) in Sardinia as assessed by SSR markers. Genet. Resour. Crop Evol. 57: 41-54.

Essadki M, Ouazzani N, Lumaret R and Moumni M (2006). ISSR variation in olive-tree cultivars from Morocco and other Western countries of the Mediterranean Basin. Genet. Resour. Crop Evol. 53: 475-482.

Ganino T, Beghè D, Valenti S, Nisi R, et al. (2007). RAPD and SSR markers for characterization and identification of ancient cultivars of Olea europaea L. in the Emilia region, Northern Italy. Genet. Resour. Crop Evol. 54: 1531-1540.

Gomes S, Martins-Lopes P, Lopes J and Guedes-Pinto H (2009). Assessing genetic diversity in Olea europaea L. using ISSR and SSR markers. Plant Mol. Biol. Rep. 27: 365-373.

Gómez-del-Campo M and Connor D (2011). Los cultivos mediterráneos en China: el caso del olivar. E.U.I.T. Agrícolas, Madri.

Kalinowski ST, Taper ML and Marshall TC (2007). Revising how the computer program CERVUS accommodates genotyping error increases success in paternity assignment. Mol. Ecol. 16: 1099-1106.

Li JH and Yu N (2012). Genetic diversity of olive cultivars in China based on fluorescent SSR markers. Sci. Silvae Scin. 48: 47-55.

Lumaret R, Ouazzani N, Michaud H, Vivier G, et al. (2004). Allozyme variation of oleaster populations (wild olive tree) (Olea europaea L.) in the Mediterranean Basin. Heredity. 92: 343-351.

Martins-Lopes P, Lima-Brito J, Gomes S, Meirinhos J, et al. (2007). RAPD and ISSR molecular markers in Olea europaea L.: Genetic variability and molecular cultivar identification. Genet. Resour. Crop Evol. 54: 117-128.

Martins-Lopes P, Gomes S, Santos E and Guedes-Pinto H (2008). DNA markers for Portuguese olive oil fingerprinting. $J$. Agric. food chemistry. 56: 11786-11791.

Montemurro C, Pasqualone A, Simeone R, Sabetta W, et al. (2008). AFLP molecular markers to identify virgin olive oils from single Italian cultivars. Europ. Food Resear. Technol. 226: 1439-1444.

Muzzalupo I, Chiappetta A, Benincasa C and Perri E (2010). Intra-cultivar variability of three major olive cultivars grown in different areas of central-southern Italy and studied using microsatellite markers. Sci. Hort. 126: 324-329.

Nei M and Li W-H (1979). Mathematical model for studying genetic variation in terms of restriction endonucleases. Proc. Nat. Acad. Sci. 76: 5269-5273.

Pafundo S, Agrimonti C, Maestri E and Marmiroli N (2007). Applicability of SCAR markers to food genomics: olive oil traceability. J. Agricul. Food Chemistry. 55: 6052-6059.

Qiu Y, Han HB, Li JQ, Hou CX, et al. (2008). RAPD Analysis of 23 olive (Olea europaea L.) cultivars. Sci. Silvae Scin. 44: 85-89.

Rallo P, Dorado G and Martin A (2000). Development of simple sequence repeats (SSRs) in olive tree (Olea europaea L.). Theor. Appl. Genet. 101: 984-989.

Roiilf F (2000). Ntsys-Pc Numerical taxonomy and multivariate analysis system version 2.1. Exeter Software, Setauket, New York. 
Saghai-Maroof M, Soliman K, Jorgensen RA and Allard R (1984). Ribosomal DNA spacer-length polymorphisms in barley: Mendelian inheritance, chromosomal location, and population dynamics. Proc. Nat. Acad. Sci. 81: 8014-8018.

Sefc K, Lopes M, Mendonça D, Santos MRD, et al. (2000). Identification of microsatellite loci in olive (Olea europaea) and their characterization in Italian and Iberian olive trees. Mol. Ecol. 9: 1171-1173.

Souza R, Ferreira JL, Braga FT, Azevedo P, et al. (2012). Outcrossing rate in olive assessed by microsatellite and inter simple sequence repeat (ISSR) markers. Afr. J. Biotechnol. 11: 11580-11584.

Trujillo I, Ojeda MA, Urdiroz NM, Potter D, et al. (2014). Identification of the Worldwide Olive Germplasm Bank of Córdoba (Spain) using SSR and morphological markers. Tree Genet. Genomes. 10: 141-155. 